\title{
Role of external ventricular drainage in spontaneous intraventricular haemorrhage patients in cileungsi district hospital
}

\author{
DOI: dx.doi.org/10.22435/hsji.v11i1.3070 \\ Feda Makkiyah ${ }^{1}$, Shelly Nobel ${ }^{1}$, Rahma Hida Nurrizka ${ }^{2}$ \\ ${ }^{1}$ Faculty of Medicine Universitas Pembangunan Nasional Veteran Jakarta \\ ${ }^{2}$ Faculty of Public Health Universitas Pembangunan Nasional Veteran Jakarta \\ Corresponding author: Feda Makkiyah \\ Email: fedamakkiyah@yahoo.com
}

Received: October 11, 2019; Revised: March 2, 2020; Accepted: March 2, 2020.

\begin{abstract}
Abstrak
Latar Belakang: Perdarahan intraventrikel otak (intraventricular haemorrhage=IVH) memperburukprognosis pada perdarahan intraserebri (intracerebral haematoma=ICH). Prosedur drainage cairan serebrospinal dari ventrikel otak (external ventricle drainage $=E V D$ ) bertujuan menurunkan tekanan intrakranial yang tinggi dikarenakan progresivitas IVH. Meskipun demikian, EVD merupakan prosedur pilihan karena terbukti tidak selalu efektif. Penelitian ini memperlihatkan faktor yang mempengaruhi keluaran pada pasien perdarahan intraventrikel dan apakah EVD memperbaiki keluaran pada pasien tersebut.
\end{abstract}

Metode: Penelitian potong-lintang retrospektif yang mengikutsertakan pasien IVH dan ICH yang berekstensi IVH(ICH-IVH) dengan EVD dan tidak di RSUD Cileungsi pada Januari sampai Desember 2018. Perbandingan antara grup EVD dan tidak berdasarkan jenis kelamin, umur, pulse pressure, Glasgow Coma Scale (GCS), jumlah perdarahan, skor volume perdarahan di ventrikel lateral, ketiga dan keempat pada CT scan, Charlson Comorbid Index (CCI) dan modified Rankin Scale (mRS). Untuk mengetahui faktor yang berperan dalam perbaikan keluaran dari pasien dengan EVD dilakukan analisis Spearman Correlation test (STATA 15).

Hasil: 100 pasien datang dengan diagnosis ICH spontan, 5 pasien IVH, dan 16 pasien ICH-IVH. Perdarahan di ventrikel empat merupakan pembeda yang signifikan antara pasien yang mendapatkan EVD atau tidak pada kelompok ICH-IVH ( $p=0,035)$. Skor GCS ( $p=0,034)$ berhubungan signifikan dengan prognosis ICH-IVH pasien dengan koefisien korelasi 0,671. EVD tidak memperbaiki keluaran dari IVH pasien atau ICH-IVH pasien.

Kesimpulan: GCS yang tinggi berkorelasi dengan prognosis baik pada grup ICH-IVH. Indikasi EVD pada adanya darah di ventrikel empat. EVD tidak memperbaiki keluaran pasien ICH-IVH spontan atau pasien IVH spontan tetapi sebaiknya dilakukan karena kemungkinan progresivitas menjadi hidrosefalus yang tipe penyumbatan yang dapat berakhir kematian. (Health Science Journal of Indonesia 2020;11(1):1-8)

Kata kunci: prognosis, IVH, ICH, EVD, RSUD Cileungsi

\begin{abstract}
Background: Intraventricular haemorrhage (IVH) worsen the prognosis of Intracerebral hematoma (ICH). External Ventricular Drain (EVD) is inserted to reduce intracranial pressure that resulted from the progression of IVH. However, EVD is still an optional procedure because it is not always proven effective. This study was aimed to demonstrate prognostic factors of IVH and whether EVD insertion might improve the outcome.

Methods: This cross-sectional retrospective study included IVH patients and concomitant ICH-IVH that required or not EVD in Cileungsi Hospital from January to December 2018. We made comparisons between EVD insertion group and non-EVD group based on sex, age, pulse pressure, Glasgow Coma Scale (GCS), bleeding volume, score of bleeding volume in ventricle lateral, third and fourth based on CT scan, Charlson Comorbid Index (CCI) and modified Rankin Scale (mRS). To determine factors contributing to the good prognosis of EVD, Spearman Correlation test was used with STATA 15 software.
\end{abstract}

Results: 100 patients were diagnosed with ICH, five patients IVH, 16 patients ICH and IVH. Blood in the fourth ventricle made a significant difference between EVD and non-EVD groups in the concomitant ICHIVH group $(p=0.035)$. GCS score $(p=0.034)$ correlated significantly with the prognosis of concomitant $\mathrm{ICH}-$ IVH patients that had EVD insertion with correlation coefficient 0.671. EVD did not improve the outcome in IVH patients nor patients with ICH-IVH.

Conclusion: EVD did not improve the prognosis of spontaneous concomitant ICH-IVH or spontaneous IVH patients, but it still needs to be inserted in case of developing obstructive hydrocephalus that might be lethal. (Health Science Journal of Indonesia 2020;11(1):1-8)

Keywords: prognosis, IVH, ICH, EVD, Cileungsi Hospital 
Intraventricular haemorrhage (IVH), a collection of blood in the ventricular system, occurs in up to $45 \%$ of patients as an extension of spontaneous intracranial hematoma $(\mathrm{ICH})$ or primary $\mathrm{IVH}$, which the bleeding source in the ventricle chamber. ${ }^{1,2}$ It is correlated with lower GCS and as a predictor of poor outcome. ${ }^{3}$ In animal models such as canine and porcine IVH models, the increased amount of blood clot in the ventricle, the likelihood death of animals. ${ }^{4}$ The same pathological process happened when blood clots expose to the ventricles leads to a decrease of cerebrospinal fluid (CSF) flow and later, inflammation, fibrosis, and hydrocephalus happened at the tissue level. ${ }^{5}$ ICH accompanying IVH in a patient is predicted to reach a mortality rate of $50 \%$ $80 \%$. Isolated or primary IVH patients are twice more likely to die, compared to a non-IVH group based on the modified Rankin Scale (mRS) when discharged from hospitals. ${ }^{6}$

Placement of ventricular catheter is increased nowadays for monitoring of intracranial pressure (ICP) and also as an adjunct to drainage CSF in acute hydrocephalus. ${ }^{7}$ However, EVD or ventriculostomy or ventricular drain has its disadvantages; mechanical complications such as dislodgement and blockade are common findings. ${ }^{8}$ These complications result in ventriculitis and meningitis that increase morbidity, hospital costs and are also difficult to treat. ${ }^{7}$

Even though many papers indicate the benefits of EVD in reducing intracranial pressure, this procedure is not adopted universally. The reasons behind this fact because several studies showed that the benefits are not seen. ${ }^{9,10}$ Some authors have opinions that it needs to determine the first benefits of EVD such as control high ICP, reduce ventricular dilatation, or drainage the blood clot from the ventricular system. Nevertheless, some agreed that EVD should be done; otherwise, the prognosis of the patients might have been worst. ${ }^{2}$ EVD is indicated for patients with massive intraventricular haemorrhage, hydrocephalus, or elevated ICP. ${ }^{11}$

Based on the uncertainty of the benefits of EVD in IVH patients, this study was done to evaluate whether EVD insertion may improve the outcome and demonstrate factors influencing the prognosis of IVH patients. The incidence of spontaneous IVH patients was low, as shown by Arboix, ${ }^{12}$ primary intraventricular haemorrhage is accounted for $0.31 \%$ of all cases of stroke and $3.3 \%$ of intracerebral hemorrhages. Different clinical series of ICH showed the prevalence of primary IVH varied greatly from
$2 \%$ in the series of Hameed ${ }^{13}$ to $7 \%$ in the series of Ara. ${ }^{14}$ There was a study that reports of 551 and only 15 of them were diagnosed with primary IVH $(2.7 \%) .{ }^{15}$ Due to the small number of IVH cases, this study included concomitant ICH cases that extend with IVH. This paper aims to evaluate the role of EVD in primary IVH and concomitant ICH cases that extend with IVH.

\section{METHODS}

All patients diagnosed with ICH (ICD-9 code 431) in Cileungsi Hospital, Bogor Regency, West Java Province, Indonesia, from January to December 2018 were included as samples of the study. This hospital was a referral hospital in Bogor Regency and with a growing population of 5,131,798 people in 2014. This hospital is equipped with a comprehensive stroke unit, and it is seeing almost 500 stroke patients in a year. ${ }^{16}$ This hospital was chosen because one neurosurgeon works and EVD was the standard of care to manage spontaneous IVH patients. Exclusion criteria were patients having craniotomy procedures, subarachnoid haemorrhage patients, traumatic ICH patients, ICH due to tumor or aneurysms, and patients with coagulation disorders. Independent variables were age, sex, pulse pressure, GCS scores, bleeding volume, scores of bleeding volume in lateral ventricles, third ventricle and fourth ventricle based on CT scan, and Charlson Comorbid Index scores (CCI). We divided each lateral ventricle with a score of 0 (no blood or a small amount of layering), 1 (up to one third filled with blood), 2 (one to two-thirds filled with blood), or 3 (mostly or completely filled with blood). The third and fourth ventricles scored 0 for no blood or 1 if they were partially or entirely filled with blood. ${ }^{17}$ The dependent variable was the modified Rankin Score (mRS). The two groups: IVH patients; ICH-IVH patients, were divided based on having EVD procedures or not. The independent variables were categorized based on mRS to find out what factors contribute to the good prognosis of EVD patients. To assess the relationship between each independent variable with $\mathrm{mRS}$, Chi Square, Fisher's exact and Spearman correlation tests were utilized using STATA software version 15. A neurosurgeon and two neurologists involved in data analysis and data grouping. Two radiology assistants were blinded to clinical outcomes and independently reviewed all the admission CT scans to verify ICH location, ICH volume, and IVH presence. (Figure 1). 


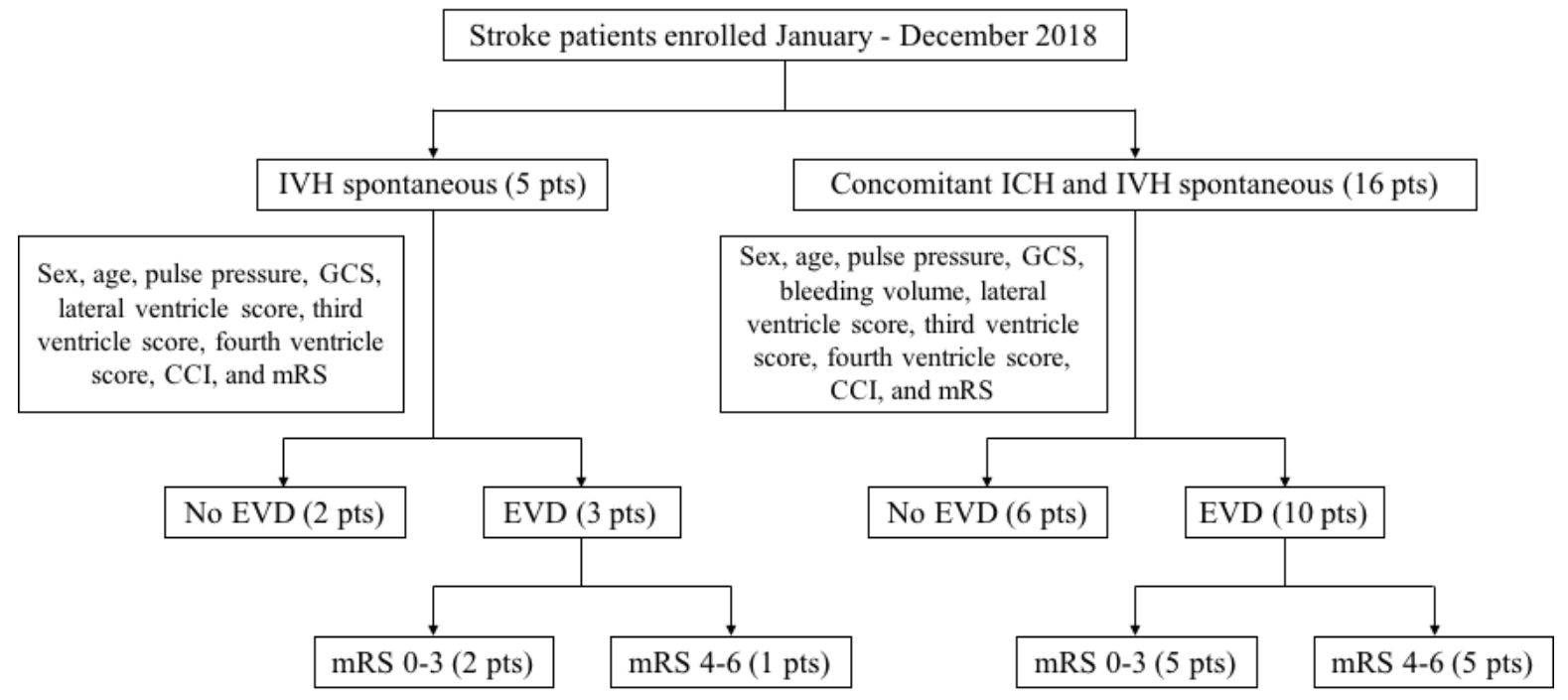

Figure 1. Schematic Diagram of Data Collection in Role of External Ventricular Drainage In Spontaneous Intraventricular Haemorrhage Patients In Cileungsi District Hospital

\section{Ethical Declaration}

Ethical approval was obtained from Universitas Pembangunan Nasional Veteran Jakarta Number B/1747/3/2019/KEPK.

\section{RESULTS}

From 313 stroke patients enrolled in Cileungsi District Hospital in 2018, 100 patients were diagnosed as spontaneous $\mathrm{ICH}$, five patients were diagnosed as primary IVH, and 16 patients had ICH-IVH. Table 1 shows characteristics for IVH patients, 3 patients with EVD, and 2 non-EVD patients. EVD was inserted in patients with head CT scan showed blood almost completely fill the lateral ventricle, blood in the third ventricle and fourth ventricle. However, the difference in blood appearance in CT scan between EVD and non-EVD groups was not significant. EVD insertion also did not demonstrate any significant improvement in the prognosis of patients $(p=1.000)$. Regarding the characteristics of IVH patients, lower age (mean age 42 years old), mean pulse pressure $67 \mathrm{mmHg}$, lower GCS (mean GCS 9) correlated not significantly with bad prognosis.

Table 2 shows the characteristics of concomitant IVH and ICH patients. EVD was inserted in patients with mean age $54,30 \pm 12,55$, mean pulse pressure $70,70 \pm 22,68$, GCS 10 , mean bleeding volume $(37,95 \pm 29,34)$, head CT scan showed blood almost completely fill the lateral ventricle, blood in the third ventricle and fourth ventricle. This was supported by a significant difference between the head CT scan showed blood in the fourth ventricle (p 0,035). EVD insertion did not improve the prognosis of patients significantly $(p=0,633)$. Characteristics of ICH and IVH that correlated with bad prognosis were mean age $59,14 \pm 14,20$, mean pulse pressure $80,57 \pm 30,84$, mean GCS 9,57 $\pm 3,78$, mean bleeding volume $38,32 \pm 26,87$. However, the correlations were not significant.

It is imperative to get a picture of what comorbid diseases that existed in both group patients (Table 3). Charlson Comorbid Indeks (CCI) up to 20 patients of both groups had peripheral vascular disease or hypertension. Severe renal diseases were diagnosed in 5 patients.

Table 4 emphasizes what factors contribute to a good outcome in ICH-IVH that had EVD insertion. Mean age $60,80 \pm 15,02$, mean pulse pressure $70,00 \pm 25,19$, mean GCS $8,40 \pm 0,5$, bleeding volume $42,79 \pm 33,50$ affected significantly the prognosis of EVD patients. Only the GCS score $(p=0,034)$ correlated significantly with a prognosis of ICH-IVH patients that had EVD insertion with coefficient correlation 0.671 . 
Table 1. Characteristics of IVH patients

\begin{tabular}{|c|c|c|c|c|c|c|c|}
\hline No & Characteristics & $\begin{array}{l}\text { Non-EVD } \\
(\mathrm{n}=2)\end{array}$ & $\begin{array}{l}\text { EVD } \\
(n=3)\end{array}$ & $p$ value & $\begin{array}{l}\text { mRS 0-3 (good } \\
\text { prognose) } \\
(\mathrm{n}=9)\end{array}$ & $\begin{array}{l}\text { mRS 4-6 } \\
\text { (bad prognose) } \\
(\mathrm{n}=7)\end{array}$ & $p$ value \\
\hline \multirow[t]{3}{*}{1} & Sex & & & 0,1 & & & 1 \\
\hline & Male & 2 & 0 & & 2 & 0 & \\
\hline & Female & 0 & 3 & & 2 & 1 & \\
\hline \multirow[t]{5}{*}{2} & Age & $(63,00 \pm 7,00)$ & $(52,67 \pm 15,40)$ & 0,136 & $(60,50 \pm 11,00)$ & 42 & 0,082 \\
\hline & $18-30$ year & 0 & 0 & & 0 & 0 & \\
\hline & $31-45$ year & 0 & 1 & & 0 & 1 & \\
\hline & $46-65$ year & 1 & 1 & & 2 & 0 & \\
\hline & $>65$ year & 1 & 1 & & 2 & 0 & \\
\hline \multirow[t]{4}{*}{3} & Pulse pressure & $(53,50 \pm 23,00)$ & $(52,33 \pm 28,04)$ & 1 & $(49,25 \pm 24,94)$ & 67 & 1 \\
\hline & $<60 \mathrm{mmHg}$ & 1 & 1 & & 2 & 0 & \\
\hline & $60-71 \mathrm{mmHg}$ & 1 & 2 & & 2 & 1 & \\
\hline & $>71 \mathrm{mmHg}$ & 0 & 0 & & 0 & 0 & \\
\hline \multirow[t]{4}{*}{4} & GCS & $(13,00 \pm 2,80)$ & $(13,00 \pm 3,40)$ & 1 & $(14 \pm 2)$ & 9 & 0,4 \\
\hline & $13-15$ & 1 & 2 & & 3 & 0 & \\
\hline & $9-12$ & 1 & 1 & & 1 & 1 & \\
\hline & $3-8$ & 0 & 0 & & 0 & 0 & \\
\hline \multirow[t]{4}{*}{5} & Lateral Ventricle & & & 0,1 & & & 1 \\
\hline & Score 1 & 0 & 0 & & 0 & 0 & \\
\hline & Score 2 & 2 & 0 & & 2 & 0 & \\
\hline & Score 3 & 0 & 3 & & 2 & 1 & \\
\hline \multirow[t]{3}{*}{6} & Third Ventricle & & & 0,1 & & & 1 \\
\hline & Score 0 & 2 & 0 & & 2 & 0 & \\
\hline & Score 1 & 0 & 3 & & 2 & 1 & \\
\hline \multirow[t]{3}{*}{7} & Fourth Ventricle & & & 0,4 & & & 1 \\
\hline & Score 0 & 2 & 1 & & 2 & 1 & \\
\hline & Score 1 & 0 & 2 & & 2 & 0 & \\
\hline \multirow[t]{3}{*}{8} & $\mathrm{CCI}$ & & & 1 & & & 0,4 \\
\hline & $1-2$ & 1 & 1 & & 1 & 1 & \\
\hline & $>2$ & 1 & 2 & & 3 & 0 & \\
\hline \multirow[t]{3}{*}{9} & $\mathrm{mRS}$ & & & 1 & & & \\
\hline & $0-3$ & 2 & 2 & & & & \\
\hline & $4-6$ & 0 & 1 & & & & \\
\hline \multirow[t]{3}{*}{10} & Mortality & & & 1 & & & \\
\hline & Alive & 2 & 2 & & 4 & 0 & 0,2 \\
\hline & dead & 0 & 1 & & 0 & 1 & \\
\hline \multirow[t]{3}{*}{11} & EVD & & & & & & \\
\hline & no & & & & 2 & 0 & 1 \\
\hline & evd & & & & 2 & 1 & \\
\hline
\end{tabular}


Table 2 Characteristics of ICH-IVH patients

\begin{tabular}{|c|c|c|c|c|c|c|c|}
\hline No & Characteristics & Non-EVD & EVD & $p$ value & mRS 0-3 & mRS 4-6 & $p$ value \\
\hline & & $(n=6)$ & $(n=10)$ & & $(n=9)$ & $(n=7)$ & \\
\hline \multirow[t]{3}{*}{1} & Sex & & & 1 & & & 0,145 \\
\hline & Male & 4 & 6 & & 4 & 6 & \\
\hline & Female & 2 & 4 & & 5 & 1 & \\
\hline \multirow[t]{5}{*}{2} & Age & $(51,17 \pm 11,27)$ & $(54,30 \pm 12,55)$ & 0,145 & $(48,44 \pm 7,24)$ & $(59,14 \pm 14,20)$ & 0,229 \\
\hline & $18-30$ year & 0 & 0 & & 0 & 0 & \\
\hline & $31-45$ year & 2 & 1 & & 2 & 1 & \\
\hline & 46-65 year & 4 & 7 & & 7 & 4 & \\
\hline & $>65$ year & 0 & 2 & & 0 & 2 & \\
\hline \multirow[t]{4}{*}{3} & Pulse pressure & $(88,67 \pm 27,19)$ & $(70,70 \pm 22,68)$ & 0,611 & $(75 \pm 21,52)$ & $(80,57 \pm 30,84)$ & 0,504 \\
\hline & $<60 \mathrm{mmHg}$ & 1 & 4 & & 3 & 2 & \\
\hline & $60-71 \mathrm{mmHg}$ & 1 & 0 & & 0 & 1 & \\
\hline & $>71 \mathrm{mmHg}$ & 4 & 6 & & 6 & 4 & \\
\hline \multirow[t]{4}{*}{4} & GCS & $(10,67 \pm 4,68)$ & $(10,60 \pm 2,99)$ & 0,726 & $(11,44 \pm 3,36)$ & $(9,57 \pm 3,78)$ & 0,499 \\
\hline & $13-15$ & 3 & 4 & & 5 & 2 & \\
\hline & $9-12$ & 1 & 2 & & 1 & 2 & \\
\hline & $3-8$ & 2 & 4 & & 3 & 3 & \\
\hline \multirow[t]{3}{*}{5} & Bleeding Volume & $(26,93 \pm 31,90)$ & $(37,95 \pm 29,34)$ & 0,118 & $(28,03 \pm 34,40)$ & $(38,32 \pm 26,87)$ & 0,302 \\
\hline & $<20 \mathrm{cc}$ & 2 & 4 & & 2 & 4 & \\
\hline & $>20 \mathrm{cc}$ & 8 & 2 & & 7 & 3 & \\
\hline \multirow[t]{4}{*}{6} & Lateral Ventricle & & & 0,837 & & & 0,683 \\
\hline & Score 1 & 2 & 4 & & 3 & 3 & \\
\hline & Score 2 & 2 & 2 & & 3 & 1 & \\
\hline & Score 3 & 2 & 4 & & 3 & 3 & \\
\hline \multirow[t]{3}{*}{7} & Third Ventricle & & & 0,299 & & & 0,308 \\
\hline & Score 0 & 3 & 2 & & 4 & 1 & \\
\hline & Score 1 & 3 & 8 & & 5 & 6 & \\
\hline \multirow[t]{3}{*}{8} & Fourth Ventricle & & & $0,035^{*}$ & & & 0,358 \\
\hline & Score 0 & 5 & 2 & & 5 & 2 & \\
\hline & Score 1 & 1 & 8 & & 4 & 5 & \\
\hline \multirow[t]{3}{*}{9} & $\mathrm{CCI}$ & & & 1 & & & 0,063 \\
\hline & $1-2$ & 5 & 8 & & 9 & 4 & \\
\hline & $>2$ & 1 & 2 & & 0 & 3 & \\
\hline \multirow[t]{3}{*}{10} & $\mathrm{mRS}$ & & & 1 & & & \\
\hline & $0-3$ & 3 & 3 & & & & \\
\hline & $4-6$ & 6 & 4 & & & & \\
\hline \multirow[t]{3}{*}{11} & Mortality & & & & & & 0,262 \\
\hline & Dead & 1 & 3 & 0,551 & 1 & 3 & \\
\hline & Alive & 5 & 7 & & 8 & 4 & \\
\hline \multirow[t]{3}{*}{12} & EVD & & & & & & \\
\hline & no & & & & 3 & 3 & 1 \\
\hline & EVD & & & & 6 & 4 & \\
\hline
\end{tabular}

Table 3. Distribution of IVH patients and concomitant ICH-IVH patients based on comorbid condition and CCI

\begin{tabular}{lccc}
\hline Condition & CCI & \multicolumn{2}{c}{ Number of patients } \\
\cline { 3 - 4 } Myocardial infarct & 1 & 0 & ICH-IVH \\
Congestive heart failure & 1 & 1 & 2 \\
Peripheral vascular disease & 1 & 4 & 1 \\
Cerebrovascular disease & 1 & 1 & 3 \\
Chronic pulmonary disease & 1 & 1 & 2 \\
Diabetes Mellitus & 1 & 1 & 0 \\
Hemiplegia & 2 & 1 & 5 \\
Moderate or severe renal disease & 2 & 2 & 3 \\
Moderate or severe liver disease & 3 & 0 & 1 \\
\hline
\end{tabular}

$\mathrm{CCI}=1$ refer to these conditions: myocardial infarct, congestive heart failure, peripheral vascular disease, cerebrovascular disease, chronic pulmonary disease, and diabetes mellitus. $\mathrm{CCI}=2$ refer to these conditions: hemiplegia and moderate or severe renal disease. $\mathrm{CCI}=3$ refer to moderate or severe liver disease. 
Table 4. Correlation of Characteristics and Prognosis Based on mRS in ICH-IVH Patients Undergone EVD Insertion

\begin{tabular}{|c|c|c|c|c|c|}
\hline No & Characteristics & $\begin{array}{c}\mathrm{mRS} 0-3 \\
(\mathrm{n}=5)\end{array}$ & $\begin{array}{c}\mathrm{mRS} 4-6 \\
(\mathrm{n}=5)\end{array}$ & $p$ value & Correlation coefficient $(\mathrm{r})$ \\
\hline \multirow[t]{3}{*}{1} & Sex & & & 0.242 & -0.408 \\
\hline & Male & 2 & 4 & & \\
\hline & Female & 3 & 1 & & \\
\hline \multirow[t]{5}{*}{2} & Age & $(47,80 \pm 4,78)$ & $(60,80 \pm 15,02)$ & 0.093 & 0.559 \\
\hline & 18-30 year & 0 & 0 & & \\
\hline & $31-45$ year & 1 & 0 & & \\
\hline & $46-65$ year & 4 & 3 & & \\
\hline & $>65$ year & 0 & 2 & & \\
\hline \multirow[t]{4}{*}{3} & Pulse pressure & $(71,4 \pm 22,8)$ & $(70,00 \pm 25,19)$ & 1.000 & 0.000 \\
\hline & $<60 \mathrm{mmHg}$ & 2 & 2 & & \\
\hline & $60-71 \mathrm{mmHg}$ & 0 & 0 & & \\
\hline & $>71 \mathrm{mmHg}$ & 3 & 3 & & \\
\hline \multirow[t]{4}{*}{4} & GCS & $(12,80 \pm 2,78)$ & $(8,40 \pm 0,5)$ & $0.034 *$ & 0.671 \\
\hline & $13-15$ & 4 & 0 & & \\
\hline & $9-12$ & 0 & 2 & & \\
\hline & $3-8$ & 1 & 3 & & \\
\hline \multirow[t]{3}{*}{5} & Bleeding Volume & $(33,09 \pm 27,49)$ & $(42,79 \pm 33,50)$ & 1.000 & 0.000 \\
\hline & $<20 \mathrm{cc}$ & 4 & 4 & & \\
\hline & $>20 \mathrm{cc}$ & 1 & 1 & & \\
\hline \multirow[t]{4}{*}{6} & Lateral Ventricle & & & 1.000 & 0.000 \\
\hline & Score 1 & 2 & 2 & & \\
\hline & Score 2 & 1 & 1 & & \\
\hline & Score 3 & 2 & 2 & & \\
\hline \multirow[t]{3}{*}{7} & Third Ventricle & & & 1.000 & 0.774 \\
\hline & Score 0 & 1 & 1 & & \\
\hline & Score 1 & 4 & 4 & & \\
\hline \multirow{3}{*}{8} & Fourth Ventricle & & & 1,000 & 0.774 \\
\hline & Score 0 & 1 & 1 & & \\
\hline & Score 1 & 4 & 4 & & \\
\hline \multirow[t]{3}{*}{9} & $\mathrm{CCI}$ & & & 1,000 & -0.200 \\
\hline & $1-2$ & 2 & 3 & & \\
\hline & $>2$ & 3 & 2 & & \\
\hline
\end{tabular}

\section{DISCUSSION}

Primary IVH is defined as bleeding that has the source and is located in the ventricular chamber. ${ }^{4}$ Around $45-70 \%$ of IVH is arising from an extension of intraparenchymal bleeding (secondary lesion) or bleeding from subarachnoid space extends into the ventricular system. ${ }^{1,2}$ Risk factors for IVH include older age,$^{18}$ as in this study, the majority of patients' age group were above 46 years old. However, 3 patients were within 31-45 years age group in ICH and IVH group. These findings are also consistent with an inpatient database study from the Netherlands based on retrospective cohort study reported that the rate of ICH per 100,000 was 5.9 in 35-54 years, 37.2 in 55-74 years, and 176.3 in 75-94 years old in 2010 . The incidence of spontaneous ICH increases with increased age. ${ }^{3}$
Pulse pressure is defined as the difference between systolic blood pressure (SBP) and diastolic blood pressure (DBP). In this study, mean pulse pressure in IVH patients that had bad prognosis was $67 \mathrm{mmHg}$, as opposed to ICH and IVH patients mean pulse pressure was $80,57 \pm 30,84 \mathrm{mmHg}$. These findings are also consistent with Chang et $\mathrm{al}^{19}$ reported mean pulse pressure of mortality after intracerebral haemorrhage was $68.5( \pm 16.4) \mathrm{mmHg}$. Widened PP might be an independent predictor for higher mortality in ICH according to a study that included 672 patients. ${ }^{19}$

Regarding GCS, there were no patients with GCS $<8$ in IVH group. In the ICH-IVH group, 6 patients were in a coma. EVD was inserted in high GCS patients such as 2 patients with GCS 13-15 in IVH patients and 4 patients in ICH-IVH patients. The reason for EVD insertion in high GCS patients was for 
ventricular drainage or ICP monitoring. As current recommendations for the management of ICH with IVH or hydrocephalus are for ICP monitoring when GCS below 8 and for ventricular drainage or when there is a decrease of consciousness. ${ }^{20}$ GCS did not make significant difference between EVD and nonEVD groups. However, there was a correlation between GCS and mRS in ICH-IVH group with EVD procedure. Higher GCS correlated with good outcomes in EVD patients as mean GCS $12,80 \pm 2,78$ of patients resulted in good $\mathrm{mRS}$ and mean GCS $8,40 \pm 0,5$ end in the poor outcome (mRS 4-6). This result was supported by Weir, who demonstrated prediction of 2-week mortality and 3-month recovery (survival, living at home) based on the GCS in a large cohort of individuals with acute stroke. He suggested that the total GCS score can predict early mortality and 3 -month recovery. ${ }^{21}$

EVD did not correlate with improved outcomes in primary IVH patients nor ICH-IVH patients in this study. This result was supported by the fact that intraventricular blood and its breakdown cause inflammation of the ependymal layer and subependymal brain tissue. Besides, the clot also causes inflammation andfibrosis of arachnoid granulations, leading to delayed communications hydrocephalus. ${ }^{4}$ This delayed process is manifested as loss of consciousness and sometimes, death. These results are consistent with Shapiro ${ }^{22}$ et al suggested that ventriculostomy to reduce dilatation of the 4th ventricle does not improve the prognosis. Adam evaluated 22 patients with spontaneous ICH and hydrocephalus concluded that EVD drainage able to reduce the ventricular volume, but the prognosis is still poor. ${ }^{23}$ Kumar collected 69 patients that treated with external ventricular drainage, and 52 patients were discharged in poor outcome. ${ }^{7}$

Comorbid conditions are best evaluated with the use of the Charlson Comorbid Indeks (CCI). CCI is an independent predictor of the death rate of surgery patients as well as long term survival. ${ }^{24}$ Peripheral vascular diseases were the most comorbid condition in both groups. High blood pressure puts the pressure on the thin arterial brain wall to rupture. As a result, brain product release into the brain tissue. This fact also supported by a study that concluded that mean arterial pressure more than $120 \mathrm{mmHg}$ was one of the risk factors of IVH. ${ }^{25}$ A study of 14 primary IVH patients, 7 patients had associated hypertension. ${ }^{26}$

As seen in Table 1,2,3, the decision to insert the EVD, more likely based on the appearance of blood in the ventricle from the CT Scan imaging. 8 patients with score 1 in 4 th ventricle and 3rd ventricle in ICH-IVH group had EVD procedure. Mean widths of the third ventricle were $4.23 \pm 1.25 \mathrm{~mm}$ and $3.81 \pm$ $0.87 \mathrm{~mm}$ in males and females respectively, whereas the mean 4th ventricular widths were, $7.87 \pm 1.30 \mathrm{~mm}$ and $7.54 \pm 1.33 \mathrm{~mm}$, in males and females. ${ }^{27}$ This small size and inflammation process than progressing after there presence of clot or progressing to hydrocephalus were the plausible reasons to insert the EVD. These reasons were supported by the $\mathrm{Naff}^{28}$ who concluded that IVH that is occluding one or both foramina of Monro or third ventricle should be managed with EVD because prone to development of hydrocephalus. A study on IVH by Stein ${ }^{29}$ inserted EVD in patients that CT scan showed complete obstruction of blood in the third ventricle or foramina Monroe. This study result showed that blood in the fourth ventricle makes a difference in EVD insertion in ICH and IVH patients. This finding is consistent with Hughes ${ }^{30}$ that concluded patients with fourth ventricle blood or dilation are more likely to benefit from EVD procedure.

Chen ${ }^{12}$ adopted other maneuvers using an endoscope tube for evacuating the blood from the ventricle. This technique was proven to reduce chronic hydrocephalus; however, the outcome of patients was still poor because the endoscope tube could not be inserted further down until the fourth ventricle and it also means that the hydrocephalus was not entirely resolved. Shapiro ${ }^{22}$ concluded that the poor outcomes of IVH related to the fourth ventricle blood clot due to brainstem compression, leading to inadequate perfusion of the brainstem.

Our study is limited in the following ways (1) the limited number of samples of the study. Some patients with massive ICH and IVH or primary IVH died before medical treatment even started. (2) Some medical records were incomplete. However, this study reinforces the data of ICH and IVH spontaneous patients in Indonesia. As our understanding, stroke is the first leading cause of disabilities and the secondhighest incidence after heart problems.

In conclusion, in our population, the decision to insert the EVD in ICH and IVH patients or primary IVH patients is solely based on the surgeons' preference. Based on our results, fourth ventricle blood significantly made a difference whether a patient requires EVD or not. Even though other characteristics did not show improving prognosis of IVH, but it still needs to be inserted in case of developing obstructive hydrocephalus that might cause the patient deceased.

\section{Acknowledgements}

The author(s) fully thanks to staff in the medical record of Cileungsi Government. 


\section{REFERENCES}

1. Hallevi H, Walker KC, Kasam M, Bornstein N, Grotta JC, Savitz SI. Inflammatory response to intraventricular hemorrhage: time course, magnitude and effect of t-PA. J Journal of the neurological sciences. 2012;315(1-2):93-5.

2. Herrick DB, Ullman N, Nekoovaght-Tak S, Hanley DF, Awad I, LeDroux S, et al. Determinants of external ventricular drain placement and associated outcomes in patients with spontaneous intraventricular hemorrhage. J Neurocritical care. 2014;21(3):426-34.

3. An SJ, Kim TJ, Yoon BW. Epidemiology, risk factors, and clinical features of intracerebral hemorrhage: an update. J Journal of stroke. 2017;19(1):3.

4. Bu Y, Chen M, Gao T, Wang X, Li X, Gao F. Mechanisms of hydrocephalus after intraventricular haemorrhage in adults. J Stroke vascular neurology. 2016;1(1):23-7.

5. Chen S, Luo J, Reis C, Manaenko A, Zhang J. Hydrocephalus after subarachnoid hemorrhage: pathophysiology, diagnosis, and treatment. J BioMed research international. 2017:8584753. doi: 10.1155/2017/8584753. Epub 2017 Mar 8.

6. Ye Z, Ai X, Hu X, Fang F, You C. Clinical features and prognostic factors in patients with intraventricular hemorrhage caused by ruptured arteriovenous malformations. J Medicine. 2017;96(45).

7. Kumar VK, Kiran NS, Kumar VA, Moscote-Salazar LR, Ghosh A, Pal R, et al. External ventricular drainage for intraventricular hemorrhage. J romanian neurosurgery. 2018:347-54.

8. Muralidharan R. External ventricular drains: management and complications. J surgical neurology international. 2015;6(Suppl 6):S271.

9. Hemphill III JC, Greenberg SM, Anderson CS, Becker K, Bendok BR, Cushman M, et al. Guidelines for the management of spontaneous intracerebral hemorrhage: a guideline for healthcare professionals from the American Heart Association/American Stroke Association. J stroke. 2015;46(7):2032-60.

10. Stretz C, Gao C, Greer DM, Loomis C, Gilmore EJ, Kundishora AJ, et al. Intracerebral Hemorrhage with intraventricular extension-getting the prognosis right early. J frontiers in neurology. 2017;8:418.

11. Dastur CK, Yu W. Current management of spontaneous intracerebral haemorrhage. J Stroke vascular neurology. 2017;2(1):21-9.

12. Arboix A, García-Eroles L, Vicens A, Oliveres M, Massons J. Spontaneous primary intraventricular hemorrhage: clinical features and early outcome. J ISRN neurology. 2012;1-7. ID 498303.

13. Hameed B, Khealani BA, Mozzafar T, Wasay M. Prognostic indicators in patients with primary intraventricular haemorrhage. Journal of Pakistan Medical Association. 2005;55(8):315.

14. Ara J, Martin J, Errea J, Bertol V, Pina M, Oliveros A. Primary intraventricular hemorrhage in the adult. J neurologia 1991;6(1):13-6.

15. Flint AC, Roebken A, Singh V. Primary intraventricular hemorrhage: yield of diagnostic angiography and clinical outcome. J Neurocritical care. 2008;8(3):330-6.

16. Makkiyah F. Summary of Cileungsi Hospital District Activity in 2019. Cileungsi: RSUD Cileungsi; 2019.

17. Shin D, Woo HJ, Park J. Spontaneous cerebellar hemorrhage with the fourth ventricular hemorrhage: risk factors associated with ventriculoperitoneal shunt. Journal of Korean Neurosurgical Society. 2012;52(4):320.

18. Weinstein R, Ess K, Sirdar B, Song S, Cutting S. Primary intraventricular hemorrhage: clinical characteristics and outcomes. J Journal of Stroke Cerebrovascular Diseases. 2017;26(5):995-9.

19. Chang JJ, Khorchid Y, Dillard K, Kerro A, Burgess LG, Cherkassky G, et al. Elevated pulse pressure levels are associated with increased in-hospital mortality in acute spontaneous intracerebral hemorrhage. American journal of hypertension 2017;30(7):719-27.

20. Hartanto RA, Jauhardin T. Outcomes of surgical management of intracerebral hemorrhagic stroke at a tertiary care center in Yogyakarta, Indonesia. Journal of the Medical Sciences. 2015;50(3).

21. Idrovo L, Fuentes B, Medina J, Gabaldón L, Ruiz-Ares G, Abenza MJ, et al. Validation of the Four Score (Spanish Version) in acute stroke: an interobserver variability study. J European neurology. 2010;63(6):364-9.

22. Shapiro SA, Campbell RL, Scully T. Hemorrhagic dilation of the fourth ventricle: an ominous predictor. Journal of neurosurgery. 1994;80(5):805-9.

23. Adams RE, Diringer MN. Response to external ventricular drainage in spontaneous intracerebral hemorrhage with hydrocephalus. J neurology. 1998;50(2):519-23.

24. Pass H, Ball D, Scagliotti G. IASLC Thoracic Oncology E-Book. Edinburgh: Elsevier Health Sciences; 2017.

25. Hinson HE, Hanley DF, Ziai WC. Management of intraventricular hemorrhage. J Current neurology. 2010;10(2):73-82.

26. Srivastava T, Sannegowda RB, Satija V, Jain R, Tejwani $\mathrm{S}$, Mathur T. Primary intraventricular hemorrhage: clinical features, risk factors, etiology, and yield of diagnostic cerebral angiography. $\mathrm{J}$ neurology india. 2014;62(2):144.

27. Hamidu AU, David SE, Olarinoye-Akorede SA, Danborno B, Jimoh A, Fatai O. Third and fourth cerebral ventricular sizes among normal adults in Zaria-Nigeria. J Sub-Saharan African Journal of Medicine. 2015;2(2):89.

28. Naff N. Intraventricular hemorrhage in adults. J current treatment options in neurology. 1999;1(3):173-8.

29. Stein M, Luecke M, Preuss M, Boeker DK, Joedicke A, Oertel MF. Spontaneous intracerebral hemorrhage with ventricular extension and the grading of obstructive hydrocephalus: the prediction of outcome of a special life-threatening entity. J neurosurgery 2010;67(5):1243-52.

30. Hughes JD, Puffer R, Rabinstein AA. Risk factors for hydrocephalus requiring external ventricular drainage in patients with intraventricular hemorrhage. Journal of neurosurgery. 2015;123(6):1439-46. 